\title{
Adult Pancreatic Hemangioma: Case Report and Literature Review
}

\author{
Gerhard S. Mundinger, ${ }^{1}$ Shannon Gust, ${ }^{2}$ Shien T. Micchelli, ${ }^{3}$ Elliot K. Fishman, ${ }^{4,5}$ \\ Ralph H. Hruban, ${ }^{3,5}$ and Christopher L. Wolfgang, 6 \\ ${ }^{1}$ Division of Plastic, Reconstructive, and Maxillofacial Surgery, The Johns Hopkins Hospital, Baltimore, MD 21218, USA \\ ${ }^{2}$ Johns Hopkins Medical School, The Johns Hopkins Hospital, Baltimore, MD 21218, USA \\ ${ }^{3}$ Department of Pathology, The Johns Hopkins Hospital, Baltimore, MD 21218, USA \\ ${ }^{4}$ Department of Radiology, The Johns Hopkins Hospital, Baltimore, MD 21218, USA \\ ${ }^{5}$ The Sol Goldman Pancreatic Cancer Research Center, The Johns Hopkins Hospital, Baltimore, MD 21218, USA \\ ${ }^{6}$ Department of Surgery, The Johns Hopkins Hospital, Baltimore, MD 21218, USA
}

Correspondence should be addressed to Gerhard S. Mundinger, gsm@jhmi.edu

Received 5 October 2008; Accepted 9 February 2009

Recommended by Andrew Thillainayagam

We report an adult pancreatic hemangioma diagnosed on pathological specimen review following pylorus preserving pancreaticoduodenectomy for a symptomatic cystic mass in the head of the pancreas. Eight cases of adult pancreatic hemangioma have been reported in literature since 1939. Presenting symptoms, radiographic diagnosis, pathologic characteristics, and treatment of adult pancreatic hemagiomas are discussed following review of all published cases.

Copyright ( $) 2009$ Gerhard S. Mundinger et al. This is an open access article distributed under the Creative Commons Attribution License, which permits unrestricted use, distribution, and reproduction in any medium, provided the original work is properly cited.

\section{Introduction}

Hemangiomas, while common in the liver, are rarely found in the pancreas. Few cases of pancreatic hemangioma presenting in adulthood have been documented. Hemangiomas are rarely suspected clinically due to their nonspecific symptoms. As a result, most are diagnosed incidentally following resection or attempted resection for symptomatic cystic pancreatic masses identified on ultrasound (US), angiography, CT, or magnetic resonance imaging (MRI). We report an adult patient with a pancreatic hemangioma diagnosed histologically following pylorus preserving pancreaticoduodenectomy (PPPD) for a symptomatic cystic lesion in the head of the pancreas.

\section{Case Report}

A 45-year-old morbidly obese woman with no significant past medical history presented to her primary care physician with 3 months of stabbing epigastric pain radiating through to her back. She was found to have a large pancreatic mass on ultrasound. A computed tomography (CT) scan at our institution demonstrated a 6.2 by $5.3 \mathrm{~cm}$ mass in the pancreatic head (Figures 1(a) and 1(b)). On arterial phase imaging, the mass was of low density relative to the pancreas without marked contrast enhancement. No adenopathy was apparent. The mass was distinct from the mesenteric vessels and therefore likely resectable (Figures $1(\mathrm{c})$ and $1(\mathrm{~d})$ ) $[1,2]$. Her serum CA 19-9 was 7.2 U/mL. Her case was reviewed at our multidisciplinary pancreatic cancer conference (http://pathology.jhu.edu/pancreas/MDC/index.html) and was felt to be a benign lesion. The differential diagnosis included duplication cyst, paraganglioma, or cystic gastrointestinal stromal tumor.

Given the patient's symptoms, she was offered surgical resection. Intraoperatively, the mass was found to be inseparable from both the duodenum and the head of the pancreas. Therefore the patient underwent a pylorus preserving pancreaticoduodenectomy without incident. Intraoperative frozen-section revealed a benign cystic lesion. The patient's postoperative course was uneventful, and she was discharged to home on postoperative day nine. 

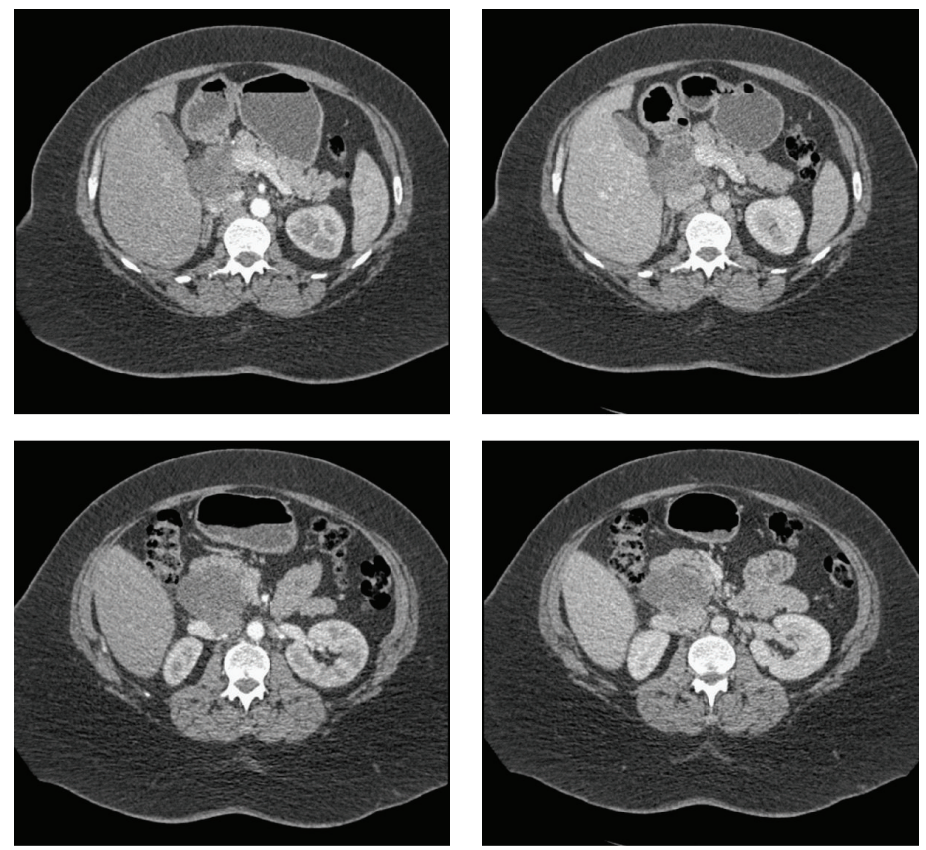

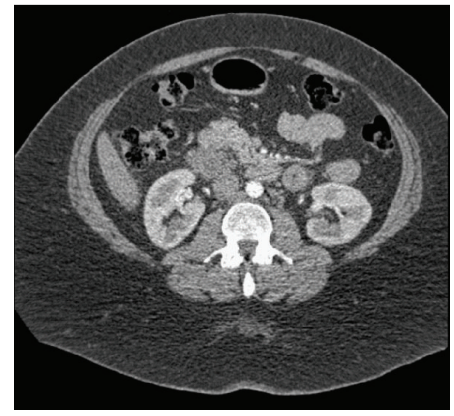

(a)

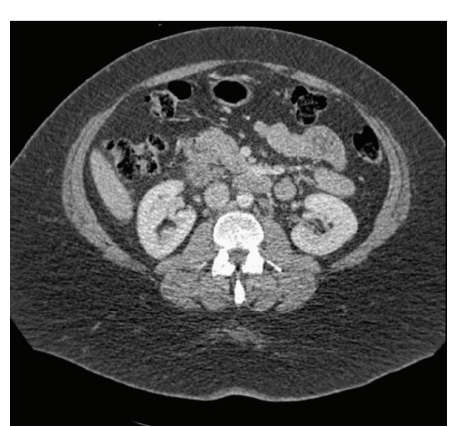

(b)

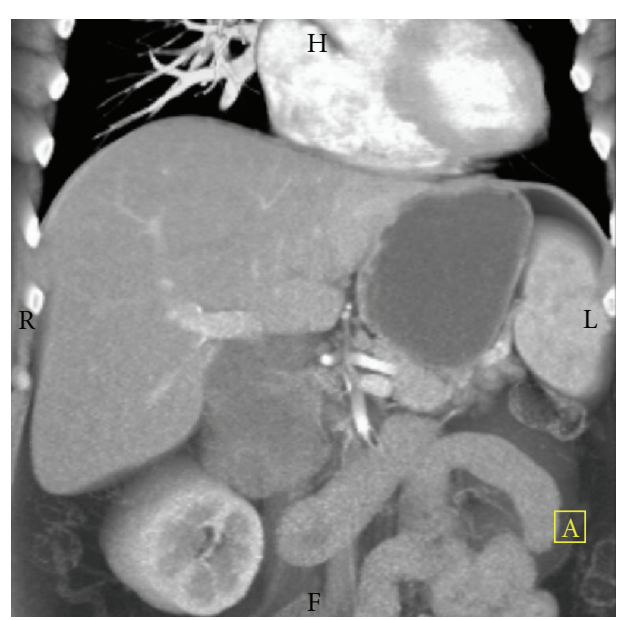

(c)

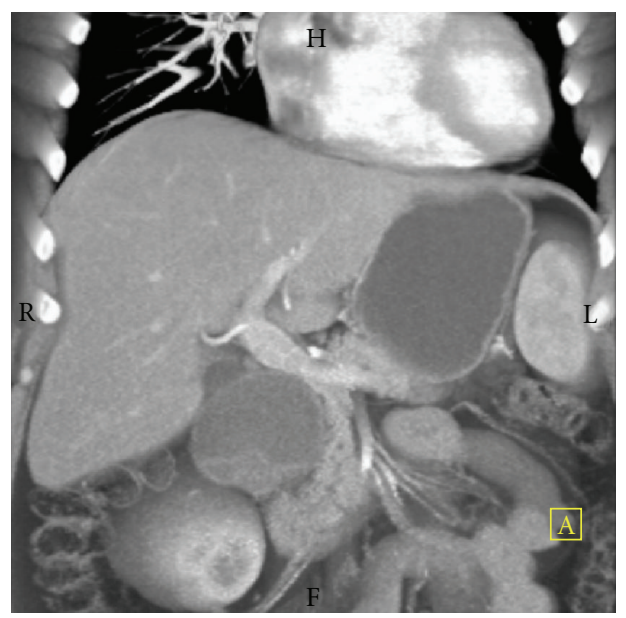

(d)

FIGURE 1: Abdominal CT scan with IV contrast demonstrating a cystic mass in the head of the pancreas. (a) Arterial phase, (b) venous phase, (c) three dimensional coronal CT reconstruction of the celiac axis illustrating resectability, and (d) three dimensional CT reconstruction of the porta hepatis.

Gross pathologic examination revealed a $5.5 \mathrm{~cm}$ hemangioma predominantly composed of denuded multiloculated cysts containing intracystic hemorrhage (Figure 2(a)). On microscopic examination, the cysts were lined by a single layer of uniform flattened cells. Immunolabeling revealed that this lining was positive for $\mathrm{CD} 31$, focally positive for CD34 and negative for cytokeratin (AE1/AE3), supporting the diagnosis of hemangioma (Figures 2(b), 2(c)). The lesion had "pushing" rather than infiltrative borders, and the endothelial cells displayed uniform nuclei without atypia. The stroma was composed of dense hyalinized collagen. All nodes and margins were negative for tumor. Background pancreatic tissue demonstrated pancreatic intraepithelial neoplasm-PanIN-1B [3].

\section{Discussion}

Pancreatic vascular neoplasms, including lymphangioma, hemangioma, hemolymphangioma, hemangiopericytoma, hemangioblastoma, and hemangiosarcoma are cystic lesions of the pancreas, collectively accounting for $0.1 \%$ of all pancreatic tumors [4]. Pancreatic hemangiomas are an extremely uncommon benign pancreatic vascular neoplasm. Adult pancreatic hemangiomas are a different pathologic entity from those that arise in the pediatric age group [5]. Pediatric (infantile) pancreatic hemangiomas undergo proliferation in infancy, only to slowly involute and regress over several years, leaving a fibro-fatty residuum by adulthood [6].

Only nine cases of adult pancreatic hemangiomas have been reported in literature since 1939 (Table 1) [7-14]. Although 5 potential cases were reported before 1939, these reports were unavailable for review [15-19]. In our institutional pancreatic database, containing over 3000 resected pancreatic specimens, we found no additional hemangiomas.

As in our case, most patients with pancreatic hemangioma present with vague abdominal pain, although one case presented with melena and hematemesis, and another with nausea and thrombocytopenia $[8,10]$. Diagnostic imaging 


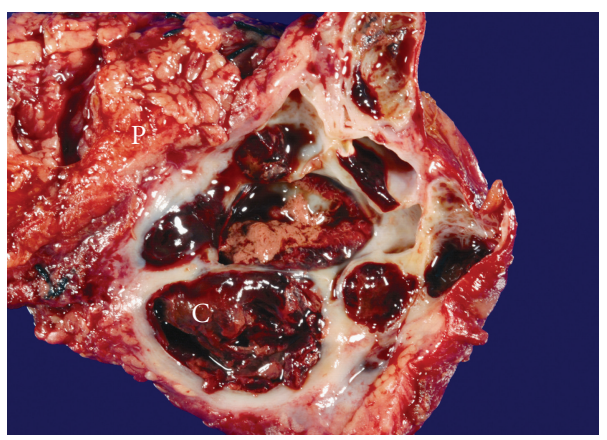

(a)

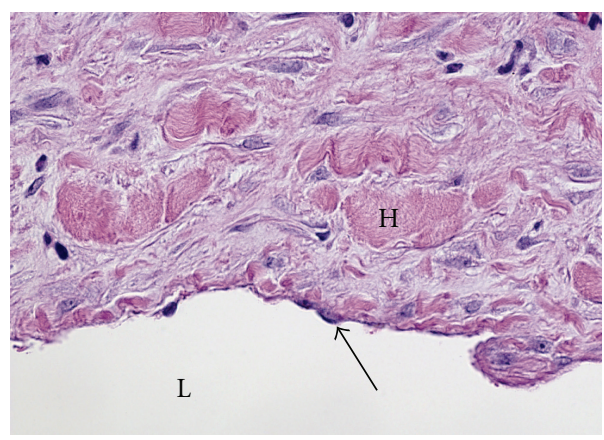

(b)

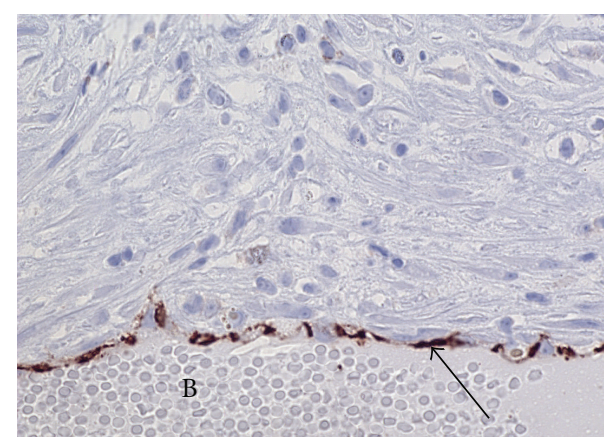

(c)

FIGURE 2: (a) Gross pathology specimen. $5.5 \mathrm{~cm}$ hemangioma containing denuded multiloculated cysts (C) with intracystic hemorrhage. Pancreatic acinar tissue (P). (b) Hematoxylin and eosin stain $(160 \mathrm{x})$ of specimen demonstrating cyst lumen (L) lined with endothelial intima (arrow) and surrounded by media rich in hyalinized collagen $(\mathrm{H}) .(\mathrm{c}) \mathrm{CD} 31$ stain $(160 \mathrm{x})$ of specimen with strong staining of endothelial intima (arrow). Blood in cyst lumen (B).

modalities used to aid in diagnosis illustrate the expected use of contemporarily available state-of-the-art imaging modalities, from plain films in the 1960s to MRI and threedimensional multiplanar CT reconstruction today.

Typically, hemangiomas are strongly contrast enhancing in the arterial phase of conventional contrast-enhanced CT imaging [11]. However, cystic tumors of the pancreas often contain areas of neovascularization with arteriovenous shunting, and blood flow through these cavernous vascular components is slow $[11,13]$. This can result in diminished contrast enhancement on arterial phase CT. The ratio of cystic to solid tissue in the neoplasm also influences the relative degree of tumor vascularity, which could also influence expected arterial phase signal intensity [20]. As our case did not demonstrate the contrast-enhanced CT features typical of a hemangioma, this was not included in our initial differential. We agree with Kobyashi et al. and Chang et al. that poor arterial phase enhancement on threephase contrast-enhanced CT cannot rule out pancreatic hemangioma $[11,13]$. This is supported by the fact that three of four pancreatic hemangiomas imaged with contrastenhanced CT did not show marked arterial phase enhancement $[11,13,14]$. Low T1w signal attenuation with high T2w signal attenuation on unenhanced MRI has been purported as a corroborative finding for pancreatic hemangioma [11].

Pathologically, the specimen was typical of a cavernous hemangioma with blood filled spaces separated by fibrous connective tissue [21]. Immunohistochemistry showed that the neoplastic cells expressed the endothelial markers CD31 and CD34, confirming that the neoplasm was of vascular endothelial origin. CD 31 and CD34 immunohistochemical labeling has been previously reported for a pediatric pancreatic hemangioma [5]. In the adult literature, labeling with antibodies to factor VIII-related antigen, a well-established marker for vascular endothelium, has been reported [13]. This is the first case of CD31 and CD34 labeling of an adult pancreatic hemangioma reported in literature.

Treatment of pancreatic hemangiomas has been variable (Table 1). Generally, a conservative approach is justified for hemangiomas given the benign nature of the lesion. However, there is a risk of bleeding, and this has been a presenting sign [8]. In this case reported by Ringoir et al., definitive resection was avoided given the patient's age and the considerably higher morbidity and mortality of pancreatic resection at the time of operation in 1959 when compared to today [22].This is the first reported case of pylorus preserving pancreaticoduodenectomy for pancreatic hemangioma.

\section{Conclusions}

Hemangiomas are rare lesions of the pancreas and are often not suspected clinically. This case of an adult pancreatic hemangioma is the ninth reported in literature since 1939 
TABLE 1: Adult pancreatic hemangiomas reported in literature since 1939.

\begin{tabular}{|c|c|c|c|c|c|c|c|c|c|c|}
\hline Case & Year & Authors & Age & Sex & Presentation & $\begin{array}{l}\text { Diagnostic } \\
\text { imaging }\end{array}$ & Location/Size & Treatment & $\begin{array}{l}\text { Pathologic } \\
\text { Description }\end{array}$ & $\begin{array}{l}\text { IHC* }^{*} \\
\text { Positivity }\end{array}$ \\
\hline$\# 1$ & 1939 & $\begin{array}{l}\text { Ranström } \\
{[7]}\end{array}$ & 61 & $\mathrm{~F}$ & $\begin{array}{l}\text { Found incidentally } \\
\text { at autopsy }\end{array}$ & - & Head $7 \times 7 \mathrm{~cm}$ & - & $\begin{array}{l}\text { Pancreatic } \\
\text { hemangioma }\end{array}$ & - \\
\hline$\# 2$ & 1961 & $\begin{array}{l}\text { Ringoir } \\
\text { et al. [8] }\end{array}$ & 71 & $\mathrm{~F}$ & $\begin{array}{l}\text { Hemetemesis, } \\
\text { melena }\end{array}$ & $\begin{array}{l}\text { Abdominal } \\
\text { plain film, } \\
\text { intravenous } \\
\text { cholangiography }\end{array}$ & $\begin{array}{l}\text { Head } 15 \mathrm{~cm} \\
\text { diameter }\end{array}$ & $\begin{array}{l}\text { Retrocolic gas- } \\
\text { troenterostomy, } \\
\text { vagotomy }\end{array}$ & $\begin{array}{l}\text { Pancreatic } \\
\text { hemangioma }\end{array}$ & - \\
\hline$\# 3$ & 1972 & $\begin{array}{l}\text { Colardyn } \\
\text { et al.[9] }\end{array}$ & 42 & M & $\begin{array}{l}\text { Abdominal/back } \\
\text { pain }\end{array}$ & $\begin{array}{l}\text { Abdominal } \\
\text { plain film, } \\
\text { angiography }\end{array}$ & Body/tail & $\begin{array}{l}\text { Fat free diet; } \\
\text { anticholinergics }\end{array}$ & - & - \\
\hline$\# 4$ & 1985 & $\begin{array}{l}\text { Mangin } \\
\text { et al. [10] }\end{array}$ & 62 & $\mathrm{~F}$ & $\begin{array}{l}\text { Malaise, nausea, } \\
\text { thrombocytopenia }\end{array}$ & $\begin{array}{l}\text { US, ERCP, CT } \\
\text { (non-contrast), } \\
\text { arteriography }\end{array}$ & $\begin{array}{l}\text { Head/body/tail } \\
20 \times 7 \mathrm{~cm}\end{array}$ & $\begin{array}{l}\text { Laparotomy, } \\
\text { observation }\end{array}$ & $\begin{array}{l}\text { Pancreatic } \\
\text { hemangioma }\end{array}$ & - \\
\hline$\# 5$ & 1991 & $\begin{array}{l}\text { Kobayashi } \\
\text { et al. [11] }\end{array}$ & 30 & M & $\begin{array}{l}\text { Abdominal } \\
\text { distention }\end{array}$ & $\begin{array}{l}\text { US, CT, } \\
\text { angiography, } \\
\text { MRI }\end{array}$ & $\begin{array}{l}\text { Head } 20 \mathrm{~cm} \\
\text { greatest dimension }\end{array}$ & $\begin{array}{l}\text { Pancreatico- } \\
\text { duodenectomy }\end{array}$ & $\begin{array}{l}\text { Pancreatic } \\
\text { hemangioma }\end{array}$ & - \\
\hline \#6 & 1991 & $\begin{array}{l}\text { Dageförde } \\
\text { et al. [12] }\end{array}$ & 79 & $\mathrm{~F}$ & Abdominal pain & $\begin{array}{l}\text { US, ERCP, } \\
\text { angiography }\end{array}$ & $\begin{array}{l}\text { Body/tail junction } \\
6 \times 3 \mathrm{~cm}\end{array}$ & Observation & - & - \\
\hline$\# 7$ & 2003 & $\begin{array}{l}\text { Chang } \\
\text { et al. [13] }\end{array}$ & 70 & $\mathrm{~F}$ & $\begin{array}{l}\text { Epigastric } \\
\text { tenderness }\end{array}$ & CT, angiography & $\begin{array}{l}\text { Body/tail junction } \\
4 \times 3.2 \mathrm{~cm}\end{array}$ & $\begin{array}{l}\text { Subtotal } \\
\text { pancreatectomy }\end{array}$ & $\begin{array}{l}\text { Pancreatic } \\
\text { hemangioma }\end{array}$ & $\begin{array}{l}\text { Factor } \\
\text { VIII- } \\
\text { related } \\
\text { antigen }\end{array}$ \\
\hline$\# 8$ & 2006 & $\begin{array}{l}\text { Plank et al. } \\
{[14]}\end{array}$ & 36 & M & Abdominal pain & $\begin{array}{l}\text { CT, MRI, } \\
\text { intraoperative } \\
\text { US }\end{array}$ & $\begin{array}{l}\text { Head } 3 \mathrm{~cm} \text { greatest } \\
\text { dimension }\end{array}$ & $\begin{array}{l}\text { Laparotomy, } \\
\text { observation }\end{array}$ & - & - \\
\hline$\# 9$ & 2008 & $\begin{array}{l}\text { Mundinger } \\
\text { et al. }\end{array}$ & 45 & $\mathrm{~F}$ & $\begin{array}{l}\text { Epigastric pain } \\
\text { radiating through } \\
\text { to back }\end{array}$ & CT, MRI & Head $6.2 \times 5.3 \mathrm{~cm}$ & $\begin{array}{l}\text { Pylorus } \\
\text { preserving } \\
\text { pancreatico- } \\
\text { duodenectomy }\end{array}$ & $\begin{array}{l}\text { Pancreatic } \\
\text { hemangioma }\end{array}$ & $\begin{array}{l}\text { CD } 31 \\
\text { CD } 34\end{array}$ \\
\hline
\end{tabular}

*Immunohistochemistry.

and is the first treated with a pylorus preserving pancreaticoduodenectomy. Review of all reported cases and relevant literature reveals that, in contrast to other hemangiomas, pancreatic hemangiomas may not contrast enhance on arterial phase CT imaging. This modality is therefore an ineffective means for ruling out pancreatic hemangioma. Understanding of the pathophysiology and natural history of these lesions remains in its infancy.

\section{References}

[1] M. G. House, C. J. Yeo, J. L. Cameron, et al., "Predicting resectability of periampullary cancer with three-dimensional computed tomography," Journal of Gastrointestinal Surgery, vol. 8, no. 3, pp. 280-288, 2004.

[2] E. K. Fishman and K. M. Horton, "Imaging pancreatic cancer: the role of multidetector CT with three-dimensional CT angiography," Pancreatology, vol. 1, no. 6, pp. 610-624, 2001.

[3] R. H. Hruban, N. V. Adsay, J. Albores-Saavedra, et al., "Pancreatic intraepithelial neoplasia: a new nomenclature and classification system for pancreatic duct lesions," American Journal of Surgical Pathology, vol. 25, no. 5, pp. 579-586, 2001.

[4] J. Le Borgne, L. de Calan, and C. Partensky, "Cystadenomas and cystadenocarcinomas of the pancreas: a multiinstitutional retrospective study of 398 cases," Annals of Surgery, vol. 230, no. 2, pp. 152-161, 1999.

[5] R. J. England, H. Woodley, C. Cullinane, P. McClean, J. Walker, and M. D. Stringer, "Pediatric pancreatic hemangioma: a case report and literature review," Journal of the Pancreas, vol. 7, no. 5, pp. 496-501, 2006.

[6] K. Takahashi, J. B. Mulliken, H. P. W. Kozakewich, R. A. Rogers, J. Folkman, and R. A. B. Ezekowitz, "Cellular markers that distinguish the phases of hemangioma during infancy and childhood," The Journal of Clinical Investigation, vol. 93, no. 6, pp. 2357-2364, 1994.

[7] V. Ranström, "Haemangioma cavernosum pancreatis," Zentralblatt für Allgemeine Pathologie und Pathologische, vol. 73, no. 2, pp. 33-35, 1939.

[8] S. Ringoir, F. Derom, R. Colle, and G. Mortier, "Hemangioma of the pancreas," Gastroenterology, vol. 41, no. 1, pp. 43-45, 1961.

[9] F. Colardyn, A. Elewaut, E. Van de Velde, and F. Barbier, "Hemangioma of the pancreas," Tijdschrift voor GastroEnterologie, vol. 15, no. 4, pp. 260-267, 1972.

[10] P. Mangin, M. Perret, and A. Ronjon, "Hémangiome du pancréas," Journal de Radiologie, vol. 66, no. 5, pp. 381-384, 1985.

[11] H. Kobayashi, T. Itoh, R. Murata, and M. Tanabe, "Pancreatic cavernous hemangioma: CT, MRI, US, and angiography 
characteristics," Gastrointestinal Radiology, vol. 16, no. 4, pp. 307-310, 1991.

[12] J. Dageförde, E. Gmelin, and M. Otte, "Hämangioma of the pancreas," Fortschr Röntgenstr, vol. 154, no. 3, pp. 332-333, 1991.

[13] W.-T. Chang, K.-T. Lee, and S.-F. Yang, "Cavernous hemangioma of the pancreas: report of a case," Pancreas, vol. 26, no. 3, pp. 310-312, 2003.

[14] C. Plank, B. Niederle, A. Ba-Ssalamah, and W. Schima, "Pancreatic hemangioma: imaging features with contrast-enhanced CT and with gadolinium- and mangafodipir-enhanced MRI," European Journal of Radiology Extra, vol. 57, no. 2, pp. 59-62, 2006.

[15] J. Baudach, "Über angioma myxomatosum des pankreas. Inaugural dissertation, reiburg, 1885," in Handbuch der Speziellen Pathologishen Anatomie und Histologie, W. Fisher and W. Gerlach, Eds., vol. 5:2, p. 498, Springer, Berlin, Germany, 1929, cited by G. B. Gruber.

[16] Walz, "Two demonstrations," Zentralblatt für Allgemeine Pathologie und Pathologische Anatomie, vol. 34, p. 620, 1924.

[17] M. Versé, "Discussion," Zentralblatt für Allgemeine Pathologie und Pathologische Anatomie, vol. 34, p. 620, 1924.

[18] Chiari, "Über angioma myxomatosum des pankreas. Inaugural dissertation, reiburg, 1885," in Handbuch der Speziellen Pathologishen Anatomie und Histologie, W. Fisher and W. Gerlach, Eds., vol. 5:2, p. 498, Springer, Berlin, Germany, 1929, cited by G. B. Gruber.

[19] N. A. Busni, "Ein fall von arterialangiom des pankreas," Frankfurter Zeitschrift für Pathologie, vol. 38, p. 81, 1929.

[20] P. C. Freeny, C. J. Weinstein, D. A. Taft, and F. H. Allen, "Cystic neoplasms of the pancreas: new angiographic and ultrasonographic findings," American Journal of Roentgenology, vol. 131, no. 5, pp. 795-802, 1978.

[21] F. J. Schoen, "Blood vessels," in Robbins and Cotran Pathologic Basis of Disease, V. Kumar, N. Fausto, and A. Abbas, Eds., pp. 545-547, WB Saunders, Philadelphia, Pa, USA, 7th edition, 2004.

[22] J. L. Cameron, T. S. Riall, J. Coleman, and K. A. Belcher, "One thousand consecutive pancreaticoduodenectomies," Annals of Surgery, vol. 244, no. 1, pp. 10-15, 2006. 


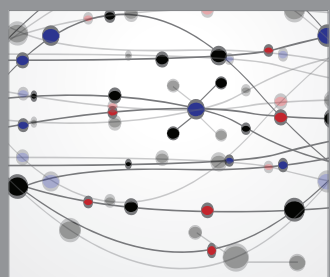

The Scientific World Journal
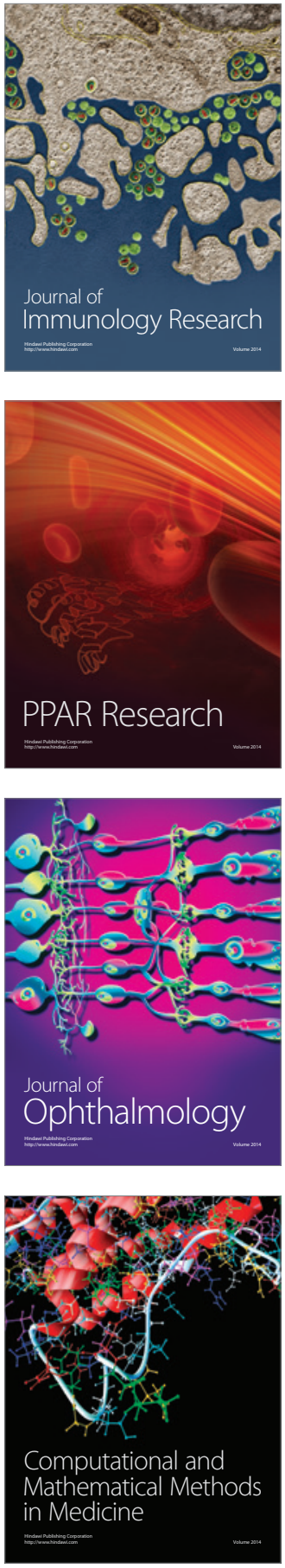

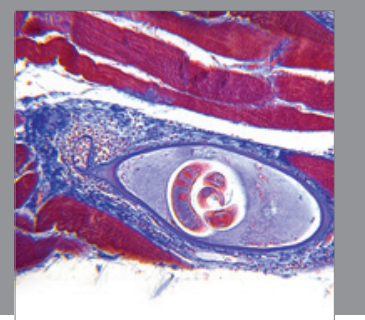

Gastroenterology

Research and Practice
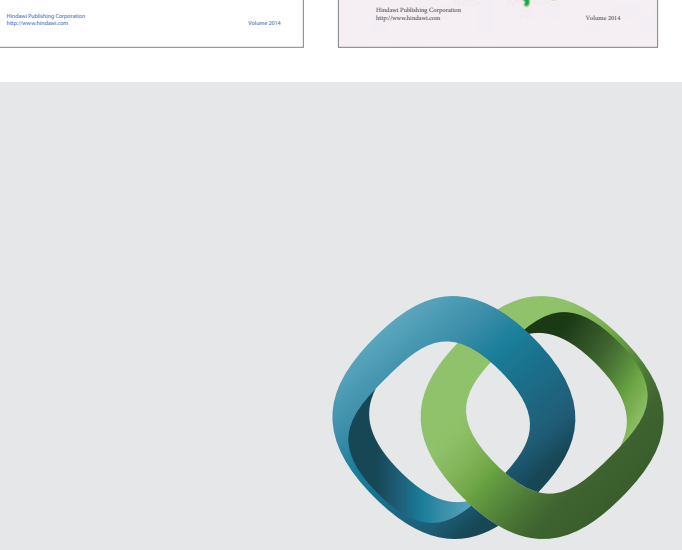

\section{Hindawi}

Submit your manuscripts at

http://www.hindawi.com
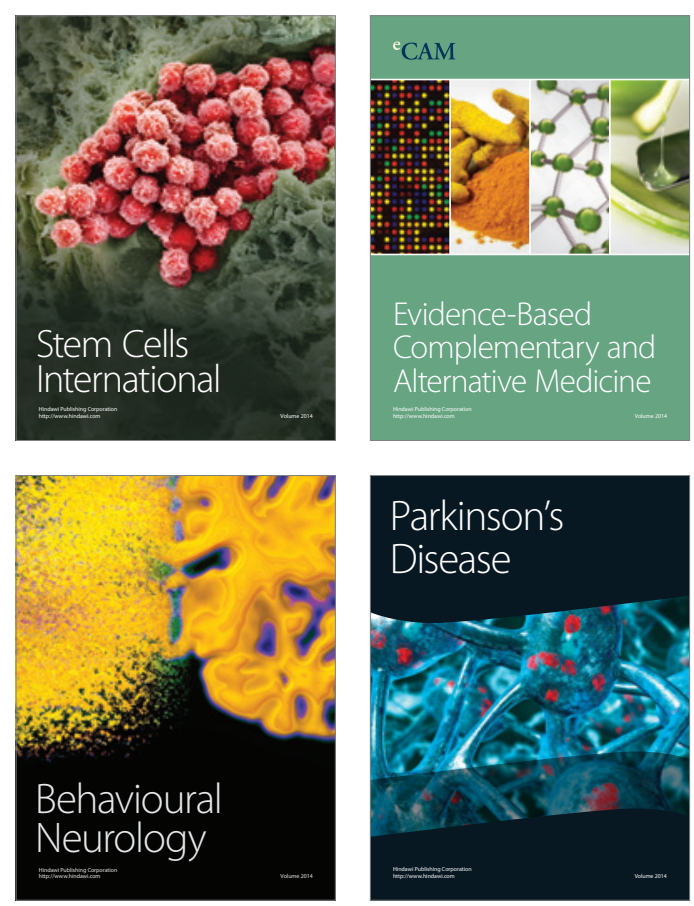

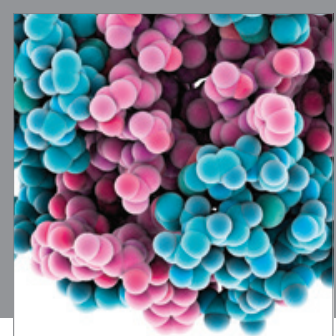

Journal of
Diabetes Research

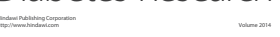

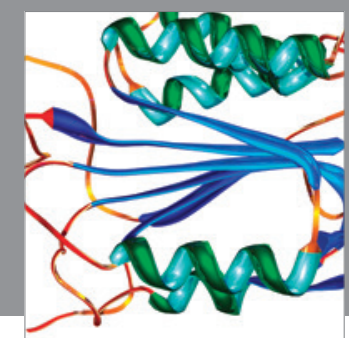

Disease Markers
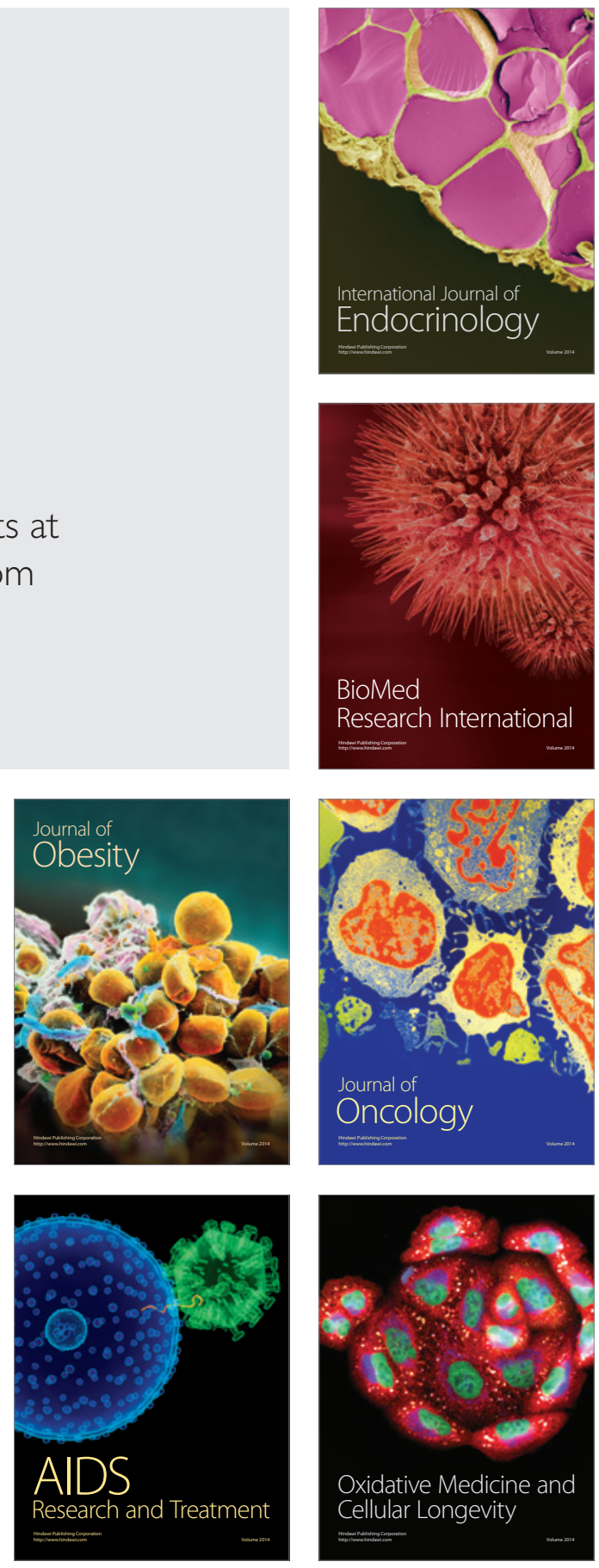